\title{
Proposal for C-Hordein as Reference Material in Gluten Quantification
}

\author{
Huang, Xin
}

2017-03-15

Huang , X, Kanerva , P , Salovaara , H , Stoddard , F L \& Sontag-Strohm , T 2017 , '

Proposal for C-Hordein as Reference Material in Gluten Quantification ' , Journal of

Agricultural and Food Chemistry , vol. 65 , no. 10 , pp. 2155-2161 . https://doi.org/10.1021/acs.jafc.6b05061

http://hdl.handle.net/10138/311265

https://doi.org/10.1021/acs.jafc.6b05061

acceptedVersion

Downloaded from Helda, University of Helsinki institutional repository.

This is an electronic reprint of the original article.

This reprint may differ from the original in pagination and typographic detail.

Please cite the original version. 
This document is confidential and is proprietary to the American Chemical Society and its authors. Do not copy or disclose without written permission. If you have received this item in error, notify the sender and delete all copies.

\section{Proposal for C-hordein as reference material in gluten quantification}

\begin{tabular}{|r|l|}
\hline Journal: & Journal of Agricultural and Food Chemistry \\
\hline Manuscript ID & jf-2016-050617.R1 \\
\hline Manuscript Type: & Article \\
\hline Date Submitted by the Author: & $\mathrm{n} / \mathrm{a}$ \\
\hline Complete List of Authors: & $\begin{array}{l}\text { Huang, Xin; University of Helsinki, Department of Food and Environmental } \\
\text { Sciences } \\
\text { Kanerva, Päivi; Fazer Mills, Oy Karl Fazer Ab } \\
\text { Salovaara, Hannu; University of Helsinki, Department of Food and } \\
\text { Environmental Sciences } \\
\text { Stoddard, Frederick; Helsingin Yliopisto Maatalous-Metsatieteellinen } \\
\text { Tiedekunta, Department of Food and Environmental Sciences } \\
\text { Sontag-Strohm, Tuula; University of Helsinki, Department of Food and } \\
\text { Environmental Sciences }\end{array}$ \\
\hline
\end{tabular}

SCHOLARONE ${ }^{m}$

Manuscripts 


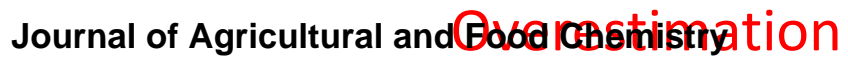

Contaminant barley

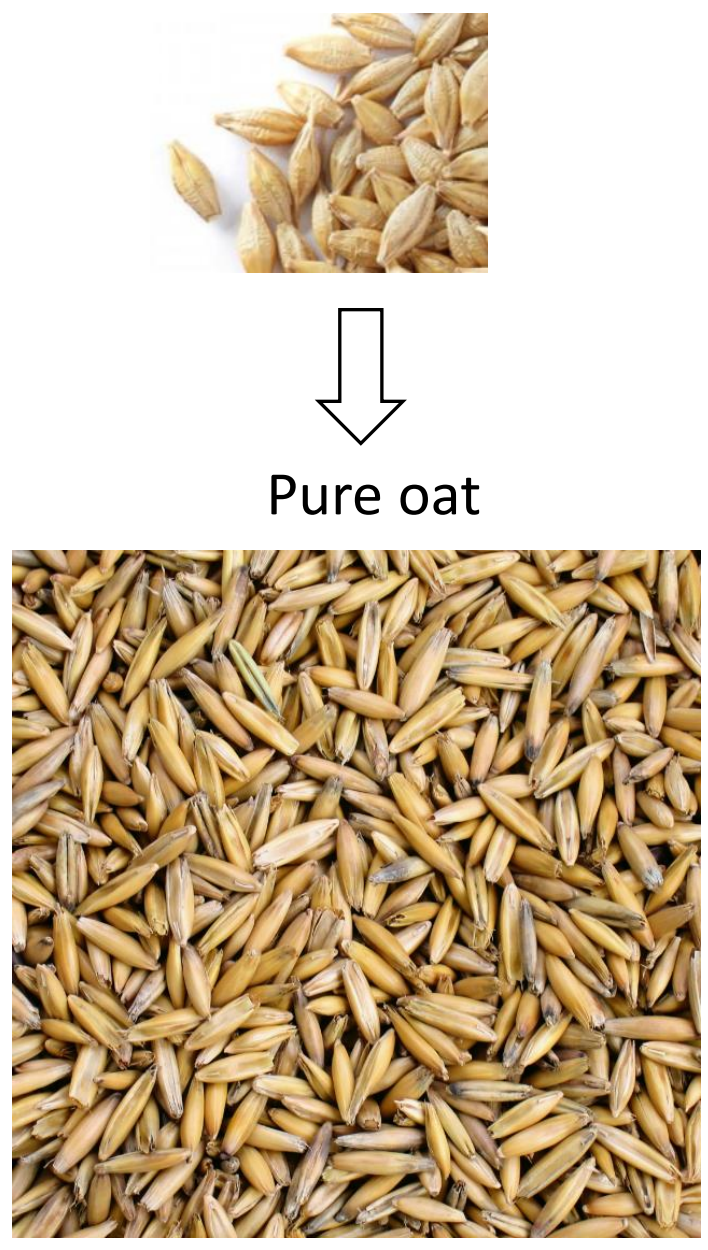

When using

gliadin as

reference material

Gluten

quantification:

Gluten-free?

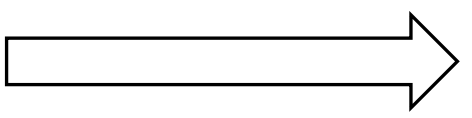

R5 sandwich ELISA

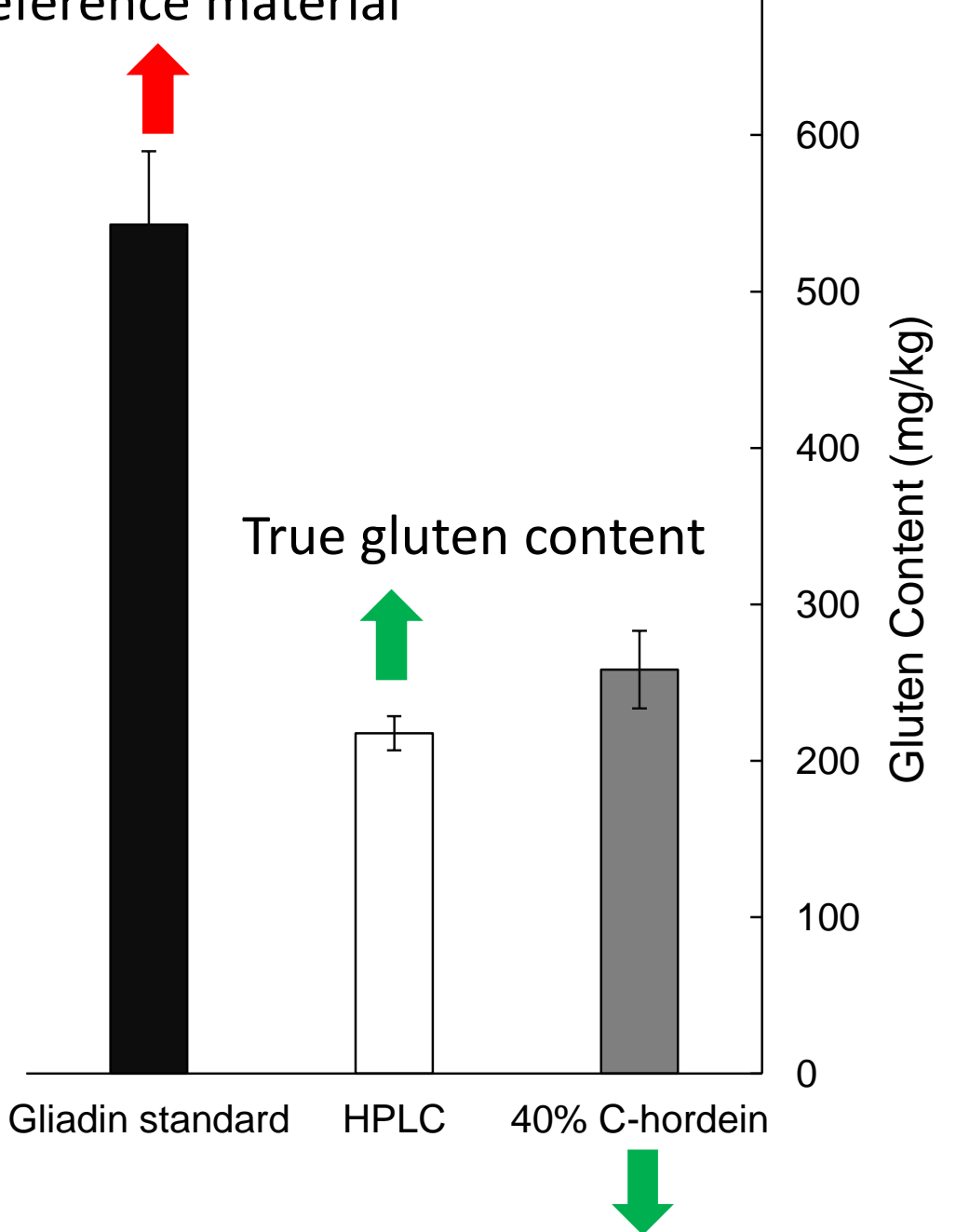

Correct content when using C-hordein as reference material 
1 Proposal for $\mathbf{C}$-hordein as reference material in gluten quantification

2

3 Xin Huanga, ${ }^{a}$, Päivi Kanerva ${ }^{b}$, Hannu Salovaara ${ }^{a}$, Frederick L. Stoddard ${ }^{a}$,

4 Tuula Sontag-Strohm ${ }^{\mathrm{a}}$

5

6 aDepartment of Food and Environmental Sciences, University of Helsinki,

7 Agnes Sjöberginkatu 2, PL 66, Helsinki FI-00014, Finland

8 bazer Mills, Oy Karl Fazer Ab, Kasakkamäentie 3, P.O Box 40, Lahti FI-

9 15101, Finland

10 *Fax:+358 919158460 Phone:+358 504485936 email:xin.huang@helsinki.fi 


\section{2}

\section{Abstract}

13 The concentration of residual barley prolamin (hordein) in gluten-free products

14 is overestimated by the R5 ELISA method when calibrated against the wheat

15 gliadin standard. The reason for this may be that the composition of the

16 gliadin standard is different from the composition of hordeins. This study

17 showed that the recognition of whole hordein by R5 antibody mainly came

18 from C-hordein, which is more reactive than the other hordeins. The

19 proportion of C-hordein in total hordein ranged from $16 \%$ to $33 \%$ of common

20 Finnish barley cultivars used in this study, and was always higher than that of

21 omega-gliadin, the homologous protein class in the gliadin standard, which

22 may account for the overestimation. Thus, a hordein standard is needed for

23 barley prolamin quantification instead of the gliadin standard. When gluten-

24 free oat flour was spiked with barley flour, the prolamin concentration was

25 overestimated 1.8-2.5 times with the gliadin standard, whereas estimates in

26 the correct range were obtained when the standard was $40 \%$ C-hordein mixed

27 with an inert protein. A preparative-scale method was developed to isolate

28 and purify C-hordein, and C-hordein is proposed as a reference material to

29 calibrate barley prolamin quantification in R5-based assays.

31 Key words: Prolamin, Gluten quantification, R5, Hordein, C-hordein, Gluten32 free 
34

35

36

37

38

\section{Introduction}

In order to predict the potential toxicity of cereal products for people with celiac disease or gluten sensitivity, gluten content is measured directly, since there is at present no assay that estimates all of the immunopathogenic elements. The currently most widely accepted method for gluten quantification is an enzyme-linked immunosorbent assay (ELISA) based on the R5 antibody. This is classified as a Type 1 method by Codex Alimentarius (standard 118-1979). With appropriate extraction, this method performs well in most food matrices when calibrated against wheat (Triticum aestivum L. emend Thell.) gliadin. In the quantification of hordein in barley-containing foods, however, the method leads to overestimation. Kanerva et al. ${ }^{1}$ reported 7-30 times overestimation when barley (Hordeum vulgare L.) contamination in oat (Avena sativa L.) was measured with a gliadin reference material. When Hernando et al. ${ }^{2}$ investigated the spiking of different barley cultivars in maize (Zea mays L.) flour, the R5 ELISA overestimated its content by 1.2 times. Later the same group ${ }^{3}$ reported that overestimation of barley in maize flour was 1.8 times, when extracted with 'cocktail solution', a phosphate-buffered saline with reducing and disaggregating agents. ${ }^{4}$ The $\mathrm{Kd}$ value, the equilibrium dissociation constant between the antibody and its antigen, of total hordein of cultivar Risø 56 against R5 antibody was 39 times greater than the that of the reference gliadin. ${ }^{5}$ There is no data suggesting that barley has greater toxicity to coeliacs than wheat, so it is important to have correct gluten quantification of barley-containing products.

One reason for the overestimation may be that the composition of gliadin 
59 reference material is substantially different from that of hordeins. The current 60 gliadin reference material is a selection of 28 European wheat cultivars, ${ }^{6}$ with $6186.4 \%$ gliadin content, including $41.7 \%$ a-gliadin, $47 \%$ y-gliadin, and $11.3 \%$ $62 \omega$-gliadin by HPLC-RP analysis. When hordein is extracted with reducing 63 agents, its typical composition is 7-8\% D-hordein (corresponding to HMW64 glutenin), $10-20 \%$ C-hordein (corresponding to $\omega$-gliadin), $70-80 \%$ B-hordein 65 (LMW-glutenins), and a minor amount of $\mathrm{Y}$-hordein (corresponding to $\mathrm{Y}$ 66 gliadin). ${ }^{7,8,9}$ Each of these protein groups has different reactivities against R5 67 antibody. The proportion of $\omega$-gliadin, which is structurally similar to C68 hordein, in total gliadin of common wheat and in the gliadin reference is less 69 than the proportion of C-hordein in total hordein.

71 The R5 antibody recognizes mainly the epitope QQPFP, and homologous 72 epitopes LQPFP, QLPYP, QQSFP, QQTFP, PQPFPF, QQPYP and PQPFP 73 to a weaker degree. ${ }^{10}$ C-hordein, the primary structure of which is almost 74 entirely repeats of $P Q Q P F P Q Q$, is strongly recognized by the R5 antibody 75 and has $15-20$ times more reactivity than the reference gliadin. ${ }^{11}$ This explains 76 the results of earlier barley overestimation.

78 Using a separate hordein reference material would make the quantification of 79 barley prolamin more accurate, as previous studies have already shown., 3,5 80 The degree of overestimation ranges widely, because each research group 81 has isolated its own hordein standard from different cultivars, so it is 82 questionable whether a single whole hordein from one cultivar could be used 83 to calibrate the hordein concentration in barley-containing products. 
85 The aim of this study was to investigate the proportion of C-hordein in whole barley hordein, in order to explain the hordein overestimation with gliadin reference material in R5 antibody-based ELISA. An additional aim was to determine whether a reference material using C-hordein could be used to quantify hordein, for example, to determine the barley contamination in oats.

\section{Materials and Methods}

\section{Materials}

Twenty-nine barley cultivars for feed and malt purposes were selected for this study. Cultivars Brage, Tocada, Vilde, Marthe, Fairytale, Aukusti, Wolmari, Barke, Polartop, Einar, Jyvä, Saana, Edvin, NFC Tipple, Streif, Harbinger, Scarlett and Elmeri were kindly provided by Boreal Plant Breeding Ltd. (Finland). The sample of Xanadu was from the Kesko Corporation (Finland), and that of Propino from Syngenta (Finland). These were the top 20 cultivars grown in Finland during 2012-2015. In addition, cultivars KWS Asta, Lacey, Minttu, Toria, Overture, Voitto, Annabel and SW Mitja (Boreal Plant Breeding Ltd.) were analyzed. Hull-less cv. Jorma was from Risto Laitinen (Villala, Finland). The barley kernels were milled to flour with a Brabender Quadrumat Junior (Duisburg, Germany) and passed through an $850 \mu \mathrm{m}$ sieve.

All the chemicals used were analytical quality or better. Bovine serum albumin (BSA) with purity $\geq 98 \%$ was purchased from Santa Cruz Biotechnology (Dallas, Texas). 
109 Hordein composition by reverse-phase high-pressure liquid 110 chromatography (RP-HPLC)

111 The hordein composition was determined by RP-HPLC. Barley flour $(0.1 \mathrm{~g})$ 112 was extracted following the Osborne sequence of $1 \mathrm{ml}$ of $\mathrm{mQ}$-water, followed 113 by $1 \mathrm{ml}$ of $0.5 \mathrm{M} \mathrm{NaCl}$, and $1 \mathrm{ml}$ of $\mathrm{mQ}$-water to remove the albumin and 114 globulin proteins at ambient temperature. After each extraction, samples were 115 centrifuged for $10 \mathrm{~min}$ at $20000 \times \mathrm{g}$. The pellet was treated either once or 3 116 times with $40 \%(\mathrm{v} / \mathrm{v})$ aqueous 1-propanol with 5\% (v/v) 2-mercaptoethanol at $11750^{\circ} \mathrm{C}$ for $30 \mathrm{~min}$ to extract the whole hordein fraction. The supernatants from 118 the three sequential extractions were bulked together. Further samples of 119 barley flour were also directly extracted either once or 3 times with the same 120 solvent. After centrifugation, the supernatants from all four of these extraction 121 types (Osborne or direct, single or triple) were filtered through a $0.45 \mu \mathrm{m}$ 122 membrane prior to RP-HPLC separation. An injection volume of $10 \mu \mathrm{l}$ of 123 whole hordein was separated on a C8 column $(4.6 \times 100 \mathrm{~mm}, 300 \AA$, $5 \mu \mathrm{m}$, 124 Discovery, Sigma-Aldrich Co. LLC), at $35^{\circ} \mathrm{C}$. A linear acetonitrile gradient from $12520 \%$ solvent $B(0.1 \%$ TFA in acetonitrile $)$ to $50 \%$ solvent $A(0.1 \%$ TFA in milli$126 \mathrm{Q}$ water) was run over $40 \mathrm{~min}$ at a flow rate of $0.7 \mathrm{ml} / \mathrm{min}$, and the elution was 127 monitored at $210 \mathrm{~nm}$. The hordein peaks were integrated (Empower 2, Waters 128 Corporation) and the peak areas were compared to determine the C-hordein 129 proportion of total hordein in each cultivar. Because the proportion of $y-$ 130 hordein was reported to be very minor, and the HPLC profile did not 131 distinguish it, it was counted together with B-hordein.

132

133 Hordein fractions reactivity against R5 antibody 
134 The hordein fractions were collected, and their protein content was quantified

135 with a BSA standard (linear range $0-60 \mu \mathrm{g}, \mathrm{R}^{2}=0.988$ ) by peak area. The

136 collected fractions were dried first under a nitrogen stream and then by

137 vacuum centrifugation (Savant SpeedVac SC110A concentrator, USA). The

138 dried fractions were completely solubilized in cocktail solution (R7006, R-

139 Biopharm, Darmstadt, Germany) and analyzed by R5 sandwich ELISA

140 (R7001, R-Biopharm, Darmstadt, Germany).

142 Purification of C-hordein in a preparative scale

143 The flour of cv. Jorma was first washed with acetone to remove phenolic 144 compounds and filtered, then extracted following the Osborne sequence 145 described earlier. The monomeric hordein was extracted with $40 \%(\mathrm{v} / \mathrm{v}) 1$ 146 propanol at $50^{\circ} \mathrm{C}$ without reducing agent. After centrifugation at $18000 \times \mathrm{g}$, 147 the supernatant was left at $4^{\circ} \mathrm{C}$ overnight. The suspension was centrifuged 148 again to remove the precipitates before mixing with buffer $A$. Buffer $A$ 149 consisted of $40 \%(\mathrm{v} / \mathrm{v})$ aqueous 1-propanol, $10 \mathrm{mM}$ glycine, and $50 \mathrm{mM}$ citric 150 acid-sodium citrate buffer at $\mathrm{pH} 3.0$, and buffer $\mathrm{B}$ consisted of $40 \%(\mathrm{v} / \mathrm{v})$ 151 aqueous 1-propanol, $0.5 \mathrm{M} \mathrm{NaCl}, 10 \mathrm{mM}$ glycine, and $50 \mathrm{mM}$ citric acid152 sodium citrate buffer at $\mathrm{pH}$ 3.0. An ion exchange column (35 mm diameter $\times$ $153300 \mathrm{~mm}$ length) was packed with TOYOPEARL SP-650M (TOSOH 154 Bioscience LLC, Japan) and coupled with ÄKTAprime plus system (GE 155 Healthcare, Sweden). After the sample was loaded, the separation gradient 156 was $0-50 \% \mathrm{~B}$ from $0 \mathrm{ml}$ to $600 \mathrm{ml}$ at a flow rate of $15 \mathrm{ml} / \mathrm{min}$. The eluate was 157 collected in $10 \mathrm{ml}$ fractions, and monitored at $280 \mathrm{~nm}$. The components of 158 fractions were analyzed by SDS-PAGE (NuPage Bis-Tris 10\%, Invitrogen, 
159 LifeTechnologies). The fractions containing C-hordein were combined and 160 dialyzed against mQ-water with a cut-off MW 10000 (Sigma-Aldrich D9527).

161 The dialysed C-hordein was lyophilized (Heto-Holton DW8-85, Denmark). For

162 the purpose of this study, this fraction was used as a benchmark of 'pure' C163 hordein.

\section{C-hordein as a reference material in sandwich and competitive ELISA}

166 Lyophilized C-hordein and BSA were dissolved separately in $60 \%(\mathrm{v} / \mathrm{v})$ 167 aqueous ethanol at $0.3 \mathrm{mg} / \mathrm{ml}$, and then mixed in ratios of $1: 9$ (C168 hordein:BSA), 2:8, 3:7, 4:6 and 5:5, further referred as $10 \%, 20 \%, 30 \%, 40 \%$, $16950 \%$ C-hordein at a constant protein concentration of $0.3 \mathrm{mg} / \mathrm{ml}$. Because 170 BSA does not react with the R5 antibody, the mixture of C-hordein with BSA 171 in different ratios was expected to mimic total hordein in ELISA. The samples 172 were tested in sandwich and competitive ELISA assays (R7021, R-Biopharm, 173 Darmstadt, Germany) to compare with the kit reference materials.

174

175 Prolamin quantification of oat flour spiked with barley flour

176 Flours of cultivars Elmeri, Einar and Marthe, with C-hordein contents of $17733.1 \%, 25.6 \%$ and $17.4 \%$, respectively, were selected for spiking in 178 commercial gluten-free oat flour (Provena, Raisio Nutrition Ltd. Finland). An 179 aliquot of $0.1 \mathrm{~g}$ of barley flour was added to $0.4 \mathrm{~g}$ whole grain oat flour and 180 homogenized by vortexing. The mix was further diluted to 400 times by oat 181 flour manually in steps $(\times 4, \times 10, \times 10)$ to ensure homogeneity. The hordein 182 concentration was also determined by R5 sandwich ELISA, and calculated 183 with gliadin reference material and 40\% C-hordein. The spiking was 
184 conducted in three replicates and each replicate was measured in two 185 dilutions, and the means and standard errors were calculated. The prolamin 186 concentration of the three barley cultivars was also determined by RP-HPLC 187 using BSA as standard by peak area. Flour was extracted with $40 \%(\mathrm{v} / \mathrm{v})$ 188 aqueous 1-propanol with 5\% (v/v) 2-mercaptoethanol and injected on a C8 189 column as described earlier.

190 


\section{Results}

\section{Hordein HPLC profile and C-hordein proportion}

193 When whole hordein was separated on a C8 column, D-hordein was eluted

194 first, followed by C-hordein and B-hordein (Figure 1)..$^{8}$ The 29 analyzed 195 cultivars could be divided into three C-hordein peak patterns, of which type 196 (b), for example cv. Barke, was the most common, present in 19 cultivars. The 197 C-hordein proportion in total hordein of cv. Elmeri after a single extraction was $19826.0 \%$ and after three sequenced extracts was $24.7 \%$; the corresponding 199 figures after Osborne extraction were $25.5 \%$ and $25.7 \%$. There was no 200 significant difference between the single and triple extraction results, so the C201 hordein content of all cultivars was determined with a single direct extraction 202 (Table 1).

203

204 From 2012 to 2015, cv. Barke and NFC Tipple were the two most popular 205 malting cultivars in Finland, accounting for over $50 \%$ of the hectarage for this 206 crop. Feed cultivars were far more diverse, with cv. Elmeri, Wolmari, Brage 207 and Aukusti accounting for over $40 \%$ of the feed barley hectarage (National 208 Land Survey of Finland, 2012-2015; http://www.maanmittauslaitos.fi/en). The 209 C-hordein content of the 29 cultivars ranged two-fold, from $16.5 \%$ to $33.1 \%$ 210 (Table 1). There was slight variation in the C-hordein content of cv. Elmeri 211 from 2010, 2014 and 2015. According to this data set, the weighted average 212 C-hordein content of whole hordein in Finland 2012-2015 was 25-26\%.

\section{Hordein subunit reactivity against R5 antibody}


215 The reactivity of D-, C- and B-hordeins against the R5 antibody varied widely

216 in sandwich ELISA (Figure 2). C-hordein was 10-20 times more reactive than

217 gliadin standard, which in turn was 8-25 times more reactive than B-hordein.

218 The slope of the curve indicated that C-hordein and gliadin standard had

219 similar affinity with the R5 antibody, while B-hordein had less, and D-hordein

220 had almost none. The three types of C-hordein and B-hordein reacted

221 similarly with R5 antibody, although their HPLC patterns were different.

222

223 Preparation of C-hordein by FPLC

224 When hordein was extracted with $40 \%$ (v/v) aqueous 1-propanol without

225 reducing agents and kept at $4^{\circ} \mathrm{C}$ overnight, precipitates appeared that were

226 mainly composed of B-hordein. At pH 3, C-hordein and B-hordein were clearly

227 separated in cation-exchange chromatography (Figure 3a). Fractions 11-15

228 (Peak 1) absorbed at $280 \mathrm{~nm}$ but did not contain prolamins, indicating that

229 they were other compounds. Fractions 17-25 (Peak 2) contained C-hordein

230 and were collected and combined in their native form. Following increased

$231 \mathrm{NaCl}$ concentration, B-hordein eluted in fractions 54-57 (Peak 3) (0.08-0.11 M

$232 \mathrm{NaCl}$ ). HPLC of lyophilized C-hordein showed its high purity in comparison

233 with the whole hordein (Figure 3b).

234

235 Purified C-hordein as reference material in ELISA

236 In sandwich ELISA, the affinity (the slope) of C-hordein with R5 antibody

237 behaved similarly with gliadin standard, and at a ratio of 3 C-hordein: 7 BSA

238 (30\% C-hordein), the reaction almost matched that of the gliadin standard

239 (Figure 4a). In competitive ELISA, the affinity of C-hordein with R5 antibody 
240 was similar to that of the peptide standard, being closest at a ratio of $1 \mathrm{C}$ -

241 hordein: 9 BSA (10\% C-hordein) (Figure 4b). Using the C-hordein and BSA in

242 different ratios could replace both the gliadin standard in R5 sandwich ELISA,

243 and the peptide standard in R5 competitive ELISA. In sandwich ELISA, the

244 curves of purified whole hordein of common cultivars, such as cvs. Barke and

245 NFC Tipple (C-hordein proportions $24.5 \%$ and $28.1 \%$ respectively), were

246 above that of the gliadin standard and between that of the $30 \%$ and $50 \%$ C-

247 hordein standard. The curve of cv. KWS Asta, with its low C-hordein content

$248(16.5 \%)$, was close to the gliadin standard curve and that of $30 \%$ C-hordein 249 (Figure 4c).

250

\section{Measuring barley contamination in oat}

252 With the same spiking, the determined prolamin concentrations of three barley

253 flours were different by HPLC, R5 sandwich with gliadin standard, and R5

254 sandwich with $40 \%$ C-hordein standard, but in the same order of Elmeri >

255 Einar > Marthe (Figure 5). The prolamin concentration calibrated by gliadin

256 standard was 2.5 times (cv. Elmeri), 1.8 times (cv. Einar), and 1.2 times (cv.

257 Marthe) the HPLC results. However, calibrated with the $40 \%$ C-hordein

258 standard, the estimated prolamin concentration was 1.2 times (cv. Elmeri),

2590.85 times (cv. Einar) and 0.63 times (cv. Marthe) the HPLC results. For cvs.

260 Elmeri and Einar, the estimated value by the $40 \%$ C-hordein standard were 261 not significantly different from those determined by HPLC, but for cv. Marthe 262 the estimate was significantly lower, until the standard was changed to $30 \%$ 263 C-hordein. 


\section{Discussion}

266 This study investigated the reasons for the overestimation of barley prolamin

267 when measured by the R5 antibody ELISA with the gliadin standard. C-

268 hordein was $80-200$ times more reactive with $\mathrm{R} 5$ antibody than B-hordein,

269 whereas D-hordein did not react significantly with R5 antibody. When

270 detecting whole hordein with $\mathrm{R} 5$, the main recognition was from C-hordein, so

271 the proportion of C-hordein in whole hordein was crucial for correct prolamin

272 quantification. The C-hordein proportion varied from $16.5 \%$ to $33.1 \%$ in

273 common barley cultivars in Finland, with an average C-hordein around $26 \%$.

274 The composition of the gliadin standard was not comparable to that of

275 hordein. Using the gliadin standard caused a 1.8-2.5 times overestimation of

276 barley flour spiked in gluten-free oat flour, but use of a $40 \%$ C-hordein

277 standard allowed calibration to give the correct concentration. A preparative-

278 scale method was developed to isolate and purify C-hordein by cation-

279 exchange chromatography, and C-hordein is proposed as a reference

280 material to calibrate barley prolamin quantification in the R5 ELISA.

282 The varying reactivity of hordein subunits against the R5 antibody is 283 attributable to the number of epitopes. The main R5 epitope, QQPFP, has 284 been shown to occur 13 times in C-hordein (Uniprot Q40055), and minor 285 epitopes QQPYP, QQTFP, PQPFP and QLPFP each occur once. One main 286 QQPFP epitope and 7 minor epitopes were found in B3 hordein (Uniprot 287 I6TEV5), and 5 QQPFP epitopes in B1 hordein (Uniprot P06470). Only one 288 QQPFP epitope was found in $\lambda 3$-hordein (Uniprot P80198) and no R5 epitope 289 was found in D-hordein (Uniprot Q84LE9). Our results agreed with those of 
290 Tanner et al. ${ }^{5}$ who measured hordein subunits of cultivars Sloop and Risø 56

291 against R5 antibody and calculated their dissociation constant (Kd) value

292 according to the best fit. In their study, the Kd value of B-hordein was 132

293 times than that of C-hordein in cv. Sloop, which means that it is much less

294 sensitive to R5 antibody. In 'Risø 56', a B-hordein null cultivar, the Kd value of

295 Y-hordein was 74 times greater than C-hordein. The $\mathrm{Kd}$ value of C-hordein

296 differed two-fold in these two cultivars. The current study showed that the C-

297 hordein of common European cultivars Harbinger, NFC Tipple and Barke 298 behaved similarly in the recognition of the R5 antibody, although their 299 peptide/protein composition as demonstrated by the HPLC profiles differed.

300 C-hordein of a single cultivar can consist of up to 20 polypeptides, thus 301 forming different HPLC profiles. The primary structures of these prolamin 302 polypeptides are highly homologous, but their molecular weights differ $^{12}$ In 303 this study, three groups of cultivars were gathered according to the RP-HPLC 304 profiles of their C-hordein, and an even more detailed classification is 305 available based on the gel patterns. ${ }^{13}$

307 The ratio of B-hordein to C-hordein in this study ranged from 1.89 for $\mathrm{cv}$. 308 Elmeri to 4.68 for cv. KWS Asta. This range is comparable to that of Scottish 309 cultivars, from 1.79 to 4.15 , determined by a similar HPLC method. ${ }^{14}$ The 310 corresponding protein group to C-hordein in wheat is $\omega$-gliadin, which shows 311 about $70 \%$ sequence homology, with a similar repetitive sequence in the 312 central domain of PFPQQPQQ. ${ }^{15}$ The $\omega$-gliadin content of total gliadin has 313 been reported to range from $6.2 \%$ to $20.0 \%,{ }^{16}$ or from $10 \%$ to $19 \%{ }^{17}$ High $\omega$ 314 gliadin proportions (17-20\%) were found in feed wheat cultivars carrying 
315 chromosome arm 1RS from rye. ${ }^{16}$ The proportion of C-hordein in total hordein

316 is generally higher than the proportion of $\omega$-gliadin in total gliadin. The

317 composition of prolamin is affected by cultivar, environment and nitrogen

318 nutrition. ${ }^{18,19}$ In a set of barley cultivars grown in Spain and Scotland, the C-

319 hordein proportion was highest in young endosperm, but at harvest ripeness,

320 the B to $C$ hordein ratio decreased slightly in Scotland while dropping much

321 lower in Spain. ${ }^{20}$ The C-hordein and $\omega$-gliadin proportion was enhanced in

322 low-sulphur growing conditions. ${ }^{21,22}$ The sulphur distribution varies in Europe,

323 for example, in central and northern Germany, Poland, most of Sweden, and

324 northern Finland, the subsoil sulphur value was lower than in northern

325 Scotland, the Netherlands, north-eastern Germany and south-eastern

326 Spain. $^{23}$ Increasing nitrogen fertilization increases both the hordein fraction of

327 whole protein and the C-hordein proportion of whole hordein. ${ }^{18}$ The proportion

328 of $\omega$-gliadin in total gliadin increases with nitrogen nutrition and

329 temperature. ${ }^{17,24,25}$

331 A C-hordein standard could be used to determine the prolamin content in, for 332 example, barley-contaminated oat, or purified barley starch, malt and malt 333 extracts. Cross-contamination of oat can occur during growing, harvest, 334 processing, storage and transportation, and the contamination of commercial 335 oat should be no more than $4 \%$. Barley is the most common contaminant in 336 oat, since they are often part of the same cropping sequence. ${ }^{2,26}$ If the 337 contaminant is suspected to be wheat, either a gliadin standard or $30 \% \mathrm{C}$ 338 hordein could be used for calibration. If the contaminant is suspected to be 339 barley, which is more likely, a C-hordein standard, based on the average C- 
340 hordein proportion of the region, can be used for calibration. The process of

341 barley starch extraction is under low $\mathrm{pH}$ so that acid hydrolysis of hordein may

342 occur, hence competitive ELISA should be utilized to detect small fragments

343 of prolamin, along with the sandwich assay. The prolamin of barley malt is

344 partially hydrolyzed by its endogenous enzymes, so it should be quantified in

345 both sandwich and competitive assays. In the sandwich assay, the current

346 commercial reference material is the gliadin standard, while in the competitive

347 assay it is a hydrolysate mixture of the gliadin standard, one barley cultivar

348 and one rye cultivar. ${ }^{27}$ Clearly, these two reference materials are not

349 comparable. In addition, the commercial peptide standard was hydrolyzed by

350 the digestive enzymes pepsin and trypsin, which is very different from the

351 malting or the starch separation process. Our results showed that the $30 \% \mathrm{C}$ -

352 hordein and BSA mixture could represent gliadin standard, while the $10 \% \mathrm{C}$ -

353 hordein mixture can represent the peptide standard. Thus, the use of a C-

354 hordein standard could not only allow correct determination of prolamin

355 content, but also make the results from sandwich and competitive assays 356 comparable.

358 Nevertheless, the validity of gliadin peptide standard for hydrolyzed products

359 has not yet been confirmed. In quantification of prolamin in spiked beer by 360 competitive R5 ELISA, calibration using gliadin peptide standard resulted in 361 overestimation by $180 \% .^{28}$ The difficulty of prolamin quantification in beer is 362 that the raw material, type and level of hydrolysis vary widely among products.

363 The peptides in the standard may not be representative of the prolamin 364 hydrolysates in beer. Competitive R5 detects peptides longer than five amino 
365 acids, but small peptides with 5-9 amino acids are considered non-toxic to

366 coeliac patients. ${ }^{29}$ New methods are under development to detect prolamin

367 peptides in beer, such as LC-MS/MS, ${ }^{30,31,32,33}$ and an ELISA method based

368 on the G12 antibody. ${ }^{34}$ Further investigations should include comparison of

369 the R5 reactivity of hordein with that of hordein peptides hydrolyzed by

370 different enzymes, and how C-hordein as reference material can represent

371 the hydrolysates in hydrolyzed products.

372

373 In analytical work, a reference material or standard is necessary. For R5-

374 based gluten analysis, the PWG gliadin standard is available, but it is not

375 reproducible, and it is not accepted as a certified reference material in the

376 Institute of Reference Material and Measurements of the European

377 Commission due to its high glutenin content (Working Group on Prolamin

378 Analysis and Toxicity, 2016; http://www.wgpat.com/pwggliadin.html).

379 Validated and certified reference material is still missing in Codex 118-1979

380 standard. C-hordein as reference material is a group of homologues of

381 proteins, rather than a mixture of gliadins from different wheat cultivars. C-

382 hordein is a better substrate for R5 antibody because its repetitive sequences

383 correspond to R5 epitopes. Additionally, the use of C-hordein as calibrant has

384 the possibility to adjust by the percentage of C-hordein. Other antibody-based

385 (G12, Skerritt, $\alpha-20)$ methods have their own reference materials. ${ }^{34,35,36}$

386 Researchers are trying to develop wheat-based reference materials

387 applicable to specific food products. ${ }^{37,38}$ 
389 In conclusion, this study determined that the high proportion of C-hordein in

390 total hordein is the reason for the consistent overestimation of hordein by the

391 R5 ELISA assay which uses gliadin as reference material in gluten-free

392 analysis. We isolated C-hordein and propose it as the reference material for

393 quantifying hordein concentration in barley-containing foods, including those

394 that may have been contaminated with barley.

395

396

397

\section{Acknowledgements}

The authors acknowledge Tekes (Center for Advancement of Technology) for

project funding, and Boreal Plant Breeding Ltd for providing barley seeds.

\section{References}

(1) Kanerva, P. M.; Sontag-Strohm, T. S.; Ryöppy, P. H.; Alho-Lehto, P.: Salovaara, H. O. Analysis of barley contamination in oats using R5 and $\omega$-gliadin antibodies. J. Cereal Sci. 2006, 44, 347-352.

(2) Hernando, A.; Mujico, J. R.; Mena, M. C.; Lombardía, M.; Mendez, E. Measurement of wheat gluten and barley hordeins in contaminated oats from Europe, the United States and Canada by Sandwich R5 ELISA. Eur. J. Gastroenterol. Hepatol. 2008, 20, 545-554.

(3) Mujico, J. R.; Mena, M. C.; Lombardía, M.; Hernando, A.; Wieser, H.; Méndez, E. On the way to reliable quantification of barley hordeins using the R5 ELISA technique. In

Proceedings of the $22^{\text {nd }}$ meeting working group on prolamin analysis and toxicity; Stern, $M$. Eds.; Verlag Wissenschaftliche Scripten: Zwickau, Germany, 2008; 29-34.

(4) López Villar, E.; Llorente Gómez, M. D. L. M.; Méndez Cormán, E. Method for extracting gluten contained in heat-processed and non-heat-processed foodstuffs, compatible with an enzyme-linked immunosorbent assay, composition and kits comprising said composition. PCT/ES2002/000208, May 3, 2002.

(5) Tanner, G. J.; Blundell, M. J.; Colgrave, M. L.; Howitt, C. A. Quantification of hordeins by ELISA: The correct standard makes a magnitude of difference. PLoS One, 2013, 8(2), e56456.

(6) Van Eckert, R.; Berghofer, E.; Ciclitira, P. J.; Chirdo, F.; Denery-Papini, S.; Ellis, H. J., Ferranti, P., Goodwin, P.; Immer, U.; Mamone, G.; Mendez, E. Towards a new gliadin reference material-isolation and characterisation. J. Cereal Sci. 2006, 43, 331-341.

(7) Shewry, P. R.; Kreis, M.; Parmar, S.; Lew, E. L.; Kasarda, D. D. Identification of Y-type hordeins in barley. FEBS Lett. 1985, 190, 61-64.

(8) Marchylo, B. A.; Kruger, J. E.; Hatcher, D. High-performance liquid chromatographic and electrophoretic analysis of hordein during malting for two barley varieties of contrasting malting quality. Cereal Chem. 1986, 63, 219-231. 
(10) Osman, A. A.; Uhlig, H. H.; Valdes, I.; Amin, M.; Méndez, E.; Mothes, T. A monoclonal antibody that recognizes a potential coeliac-toxic repetitive pentapeptide epitope in gliadins. Eur. J. Gastroenterol. Hepatol. 2001, 13, 1189-1193.

(11) Huang, X.; Kanerva, P.; Salovaara, H.; Sontag-Strohm, T. Degradation of C-hordein by metal-catalysed oxidation. Food Chem. 2016, 196, 1256-1263.

(12) Tatham, A. S.; Drake, A. F.; Shewry, P. R. Conformational studies of a synthetic peptide corresponding to the repeat motif of C hordein. Biochemical J. 1989, 259, 471-476.

(13) Shewry, P. R.; Pratt, H. M.; Miflin, B. J. Varietal identification of single seeds of barley by analysis of hordein polypeptides. J. Sci. Food Agr. 1978, 29, 587-596.

(14) Griffiths, D. W. The ratio of B to C hordeins in barley as estimated by high performance liquid chromatography. J. Sci. Food Agr. 1987, 38, 229-235.

(15) Tatham, A. S.; Shewry, P. R. The S-poor prolamins of wheat, barley and rye: revisited. J. Cereal Sci. 2012, 55, 79-99.

(16) Wieser, H.; Seilmeier, W.; Belitz, H. D. Quantitative determination of gliadin subgroups from different wheat cultivars. J. Cereal Sci. 1994, 19, 149-155.

(17) Daniel, C.; Triboi, E. Effects of temperature and nitrogen nutrition on the grain composition of winter wheat: effects on gliadin content and composition. J. Cereal Sci. 2000, $32,45-56$.

(18) Kirkman, M. A.; Shewry, P. R.; Miflin, B. J. The effect of nitrogen nutrition on the lysine content and protein composition of barley seeds. J. Sci. Food Agr. 1982, 33, 115-127.

(19) Eagles, H. A.; Bedggood, A. G.; Panozzo, J. F.; Martin, P. J. Cultivar and environmental effects on malting quality in barley. Crop Pasture Sci. 1995, 46, 831-844.

(20) Swanston, J. S.; Ellis, R. P.; Perez-Vendrell, A.; Voltas, J.; Molina-Cano, J. L. Patterns of barley grain development in Spain and Scotland and their implications for malting quality. Cereal Chem. 1997, 74, 456-461.

(21) Rahman, S.; Shewry, P. R.; Forde, B. G.; Kreis, M.; Miflin, B. J. Nutritional control of storage-protein synthesis in developing grain of barley (Hordeum vulgare L.). Planta, 1983, 159, 366-372.

(22) Shewry, P. R.; Tatham, A. S.; Halford, N. G. Nutritional control of storage protein synthesis in developing grain of wheat and barley. Plant Growth Regul. 2001, 34, 105-111.

(23) Salminen, R.; Batista, M. J.; Bidovec, M.; Demetriades, A.; De Vivo, B.; De Vos, W.; Duris, M.; Gilucis, A.; Gregorauskiene, V.; Halamić, J.; Heitzmann, P. S-Sulphur. In Geochemical atlas of Europe, part 1, background information, methodology and maps; Salminen, R. Eds.; Geological survey of Finland: Espoo, Finland, 2005, 311-317.

(24) Sollid, L. M. Coeliac disease: dissecting a complex inflammatory disorder. Nat. Rev. Immunol. 2002, 2, 647-655.

(25) DuPont, F. M.; Hurkman, W. J.; Vensel, W. H.; Chan, R.; Lopez, R.; Tanaka, C. K.; Altenbach, S. B. Differential accumulation of sulfur-rich and sulfur-poor wheat flour proteins is affected by temperature and mineral nutrition during grain development. J. Cereal Sci. 2006, $44,101-112$. 

contamination in the Canadian commercial oat supply. Food Addi. Contam. 2011, 28, 705710.

(27) Gessendorfer, B.; Koehler, P.; Wieser, H. Preparation and characterization of enzymatically hydrolyzed prolamins from wheat, rye, and barley as references for the immunochemical quantitation of partially hydrolyzed gluten. Anal. Bioanal. Chem. 2009, 395, 1721-1728.

(28) Panda, R.; Zoerb H. F.; Cho, C. Y.; Jackson, L. S.; Garber, E. A. Detection and quantification of gluten during the brewing and fermentation of beer using antibody-based technologies. J. Food Prot. 2015, 78, 1167-1177.

(29) Sollid, L. M. Coeliac disease: dissecting a complex inflammatory disorder. Nat. Rev. Immunol. 2002, 2, 647-655.

(30) Colgrave, M. L.; Goswami, H.; Howitt, C. A.; Tanner, G. J. What is in a beer? Proteomic characterization and relative quantification of hordein (gluten) in beer. J. Proteome Res. 2011, 11, 386-396.

(31) Colgrave, M. L.; Goswami, H.; Blundell, M.; Howitt, C. A.; Tanner, G. J. Using mass spectrometry to detect hydrolysed gluten in beer that is responsible for false negatives by ELISA. J. Chromatogr. A, 2014, 1370, 105-114.

(32) Tanner, G. J.; Colgrave, M. L.; Blundell, M. J.; Goswami, H. P.; Howitt, C. A. Measuring hordein (gluten) in beer-a comparison of ELISA and mass spectrometry. PLoS One, 2013, $8(2)$, e56452.

(33) Allred, L. K.; Sealey Voyksner, J. A.; Voyksner, R. D. Evaluation of qualitative and quantitative immunoassays to detect barley contamination in gluten-free beer with confirmation using LC/MS/MS. J. AOAC Int. 2014, 97, 1615-1625.

(34) Comino, I.; Real, A.; de Lourdes Moreno, M.; Montes, R.; Cebolla, Á.; Sousa, C. Immunological determination of gliadin 33-mer equivalent peptides in beers as a specific and practical analytical method to assess safety for celiac patients. J. Sci. Food Agr. 2013, 93, 933-943.

(35) Mujico, J.R.; Dekking, L.; Kooy-Winkelaar, Y.; Verheijen, R.; Wichen, P.V.; Streppel, L.; Sajic, N.; Drijfhout, J.W.; Koning, F. Validation of a new enzyme-linked immunosorbent assay to detect the triggering proteins and peptides for celiac disease: interlaboratory study. $J$. AOAC Int. 2012, 95, 206-215.

(36) Skerritt, J.H.; Hill, A.S. Monoclonal antibody sandwich enzyme immunoassays for determination of gluten in foods. J. Agric. Food Chem. 1990, 38, 1771-1778.

(37) Bugyi, Z.; Török, K.; Hajas, L.; Adonyi, Z.; Poms, R. E.; Popping, B.; Tömösközi, S.. Development of incurred reference material for improving conditions of gluten quantification. J. AOAC Int. 2012, 95, 382-387.

(38) Alvarez, P. A.; Mongeon, V. J.; Boye, J. I. Characterization of a gluten reference material: Wheat-contaminated oats. J. Cereal Sci. 2013, 57, 418-423. 
545 Figure 1. Reverse-phase liquid chromatogram of total hordein extract 546 separated on a C8 column. (a) cv. Harbinger; (b) cv. Barke; (c) cv. NFC 547 Tipple. The total hordein was directly extracted with $40 \%$ (v/v) 1-propanol with $5485 \%(v / v)$ 2-mercaptoethanol from barley flour.

550 Figure 2 Reaction of isolated hordeins against R5 antibody in sandwich 551 ELISA. Three types of C-hordein and B-hordein were from cultivars 552 Harbinger, Barke and NFC Tipple. D-hordein was from cv. Harbinger.

553

554 Figure 3 (a) Cation-exchange chromatogram of hordein. The black line shows

555 the absorbance at $280 \mathrm{~nm}$, fractions from peaks 1, 2 and 3 were collected, 556 and the red line shows the gradient concentration of $\mathrm{NaCl}$. The inset shows 557 SDS-PAGE of collected fractions; (b) Reverse-phase chromatogram of 558 purified C-hordein and whole hordein from cv. Jorma.

560 Figure 4 Reaction of C-hordein mixed with bovine serum albumin (BSA) in 561 different ratios against R5 antibody (a) in sandwich ELISA; and (b) in 562 competitive ELISA. (c) Reaction of purified whole hordein of 6 cultivars in R5 563 sandwich ELISA compared with $30 \%, 40 \%$ and $50 \%$ C-hordein standards and 564 gliadin standard.

565

566 Figure 5 Prolamin concentration of gluten-free oat flour spiked with three

567 barley flours, determined by HPLC, R5 sandwich ELISA with 40\% C-hordein

568 standard, and R5 sandwich ELISA with gliadin standard. Error bars show

569 standard error. 
570 Table 1 C-hordein content as percentage of whole hordein of selected barley

571 cultivars.

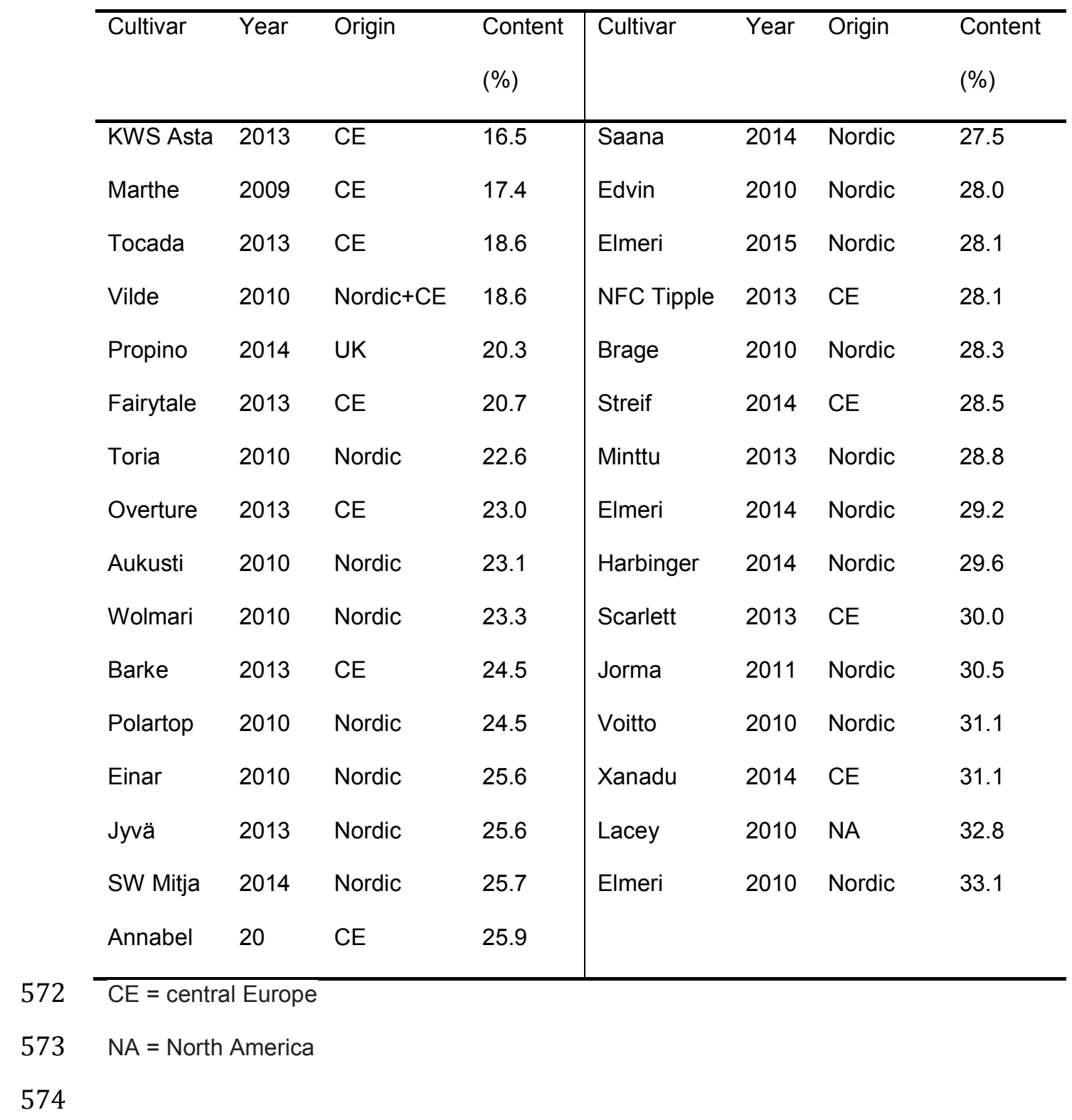


575 Figure 1

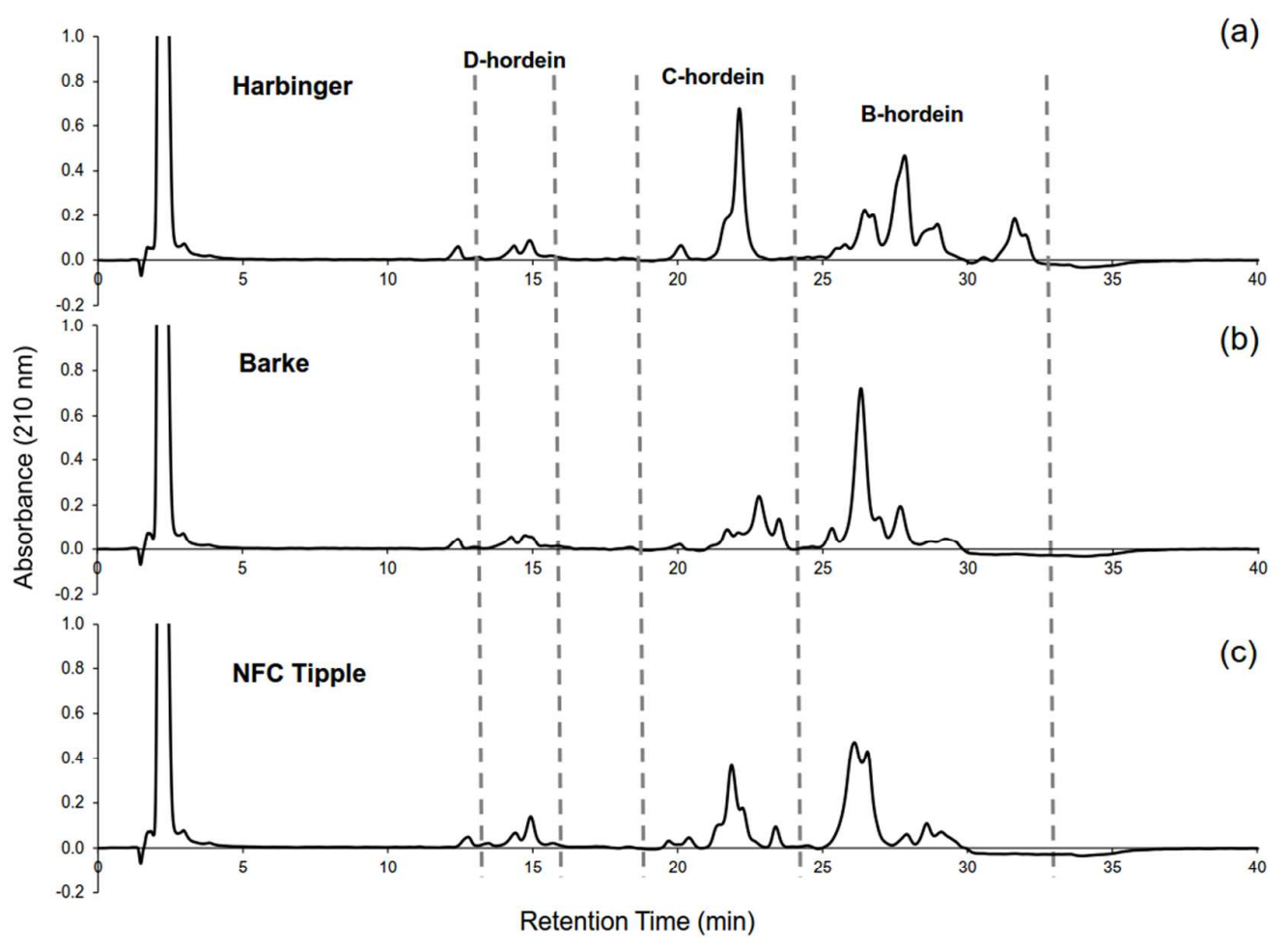

576 
$578 \quad$ Figure 2

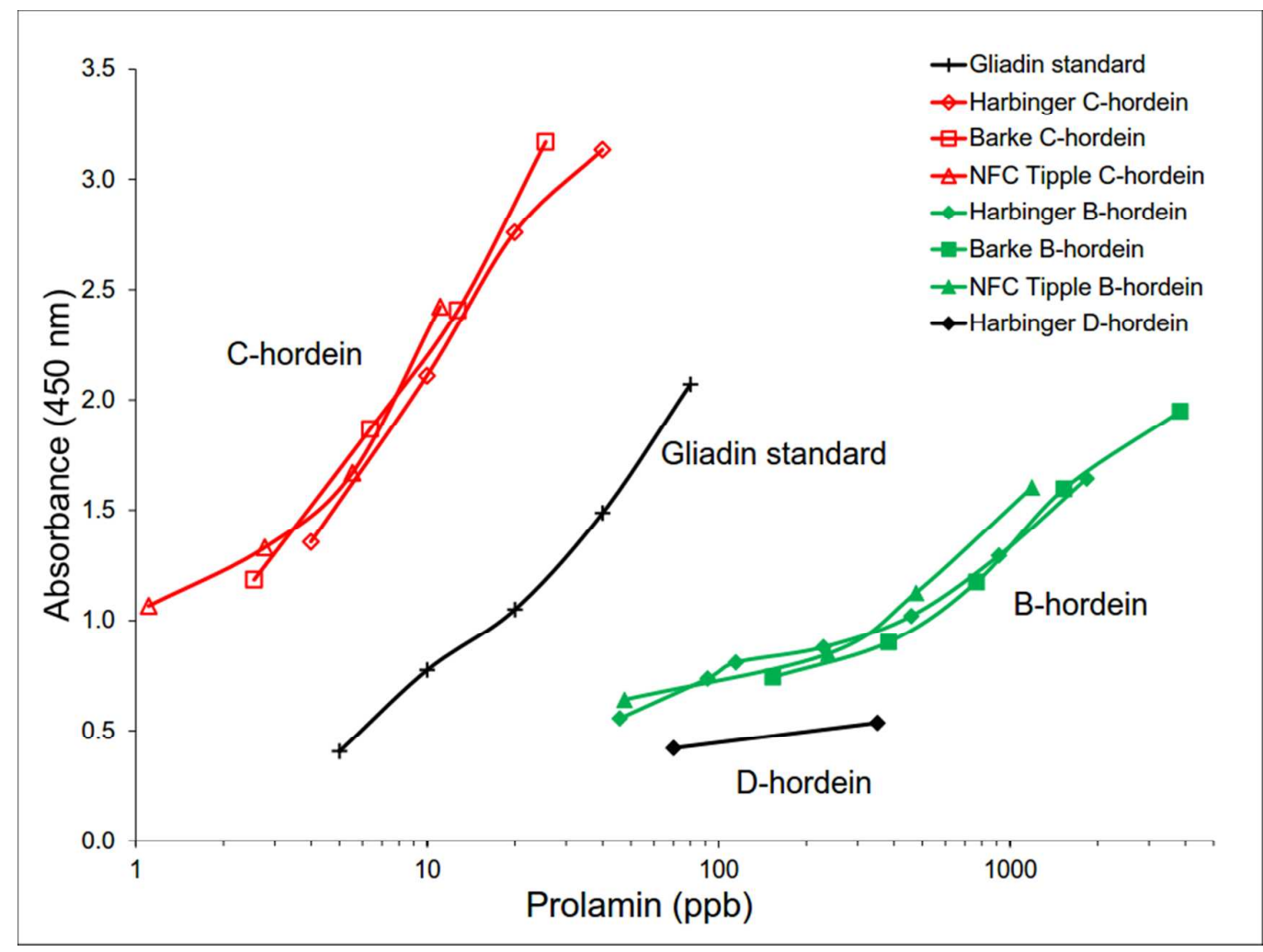

580 
Figure 3
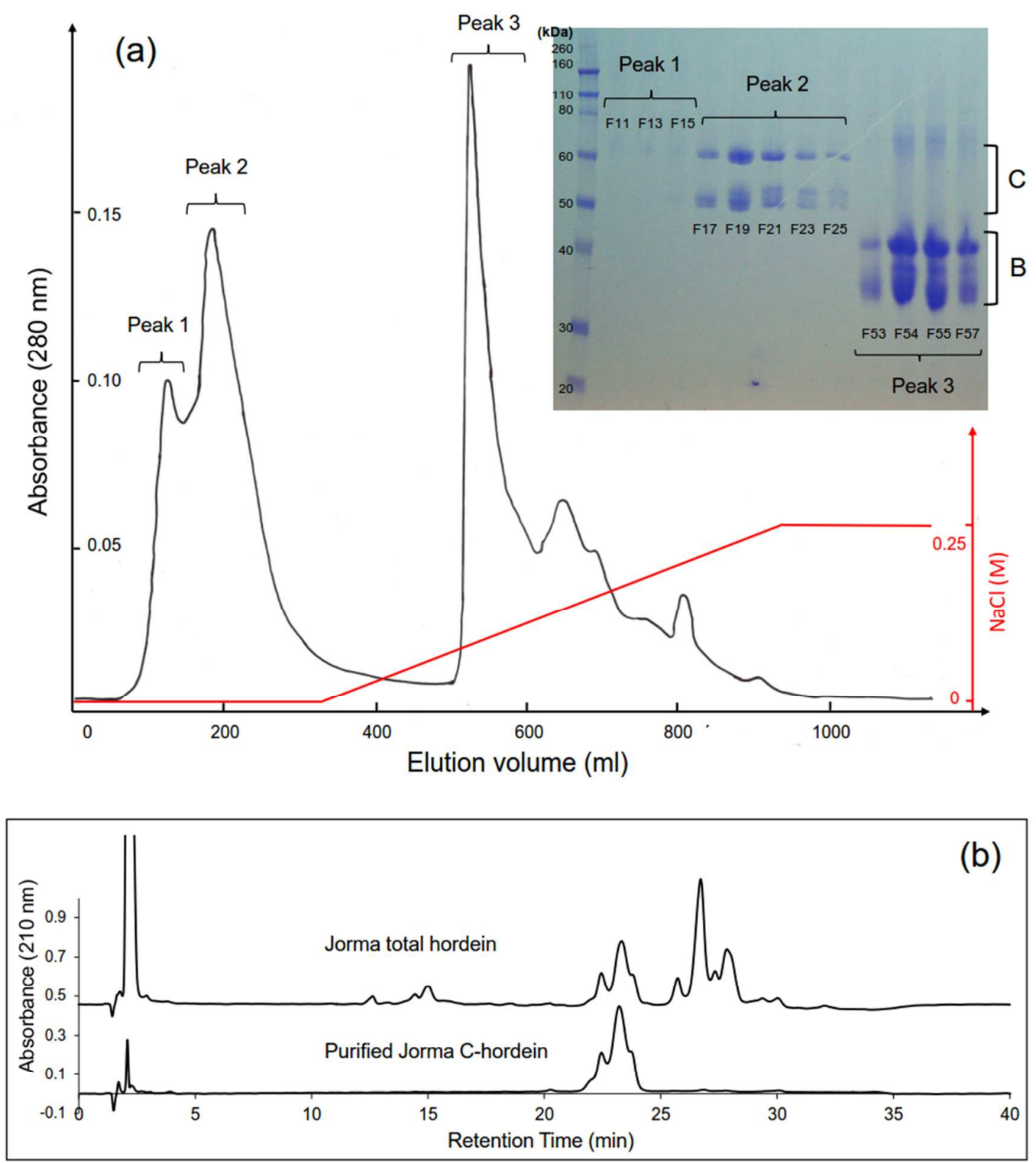
Figure 4
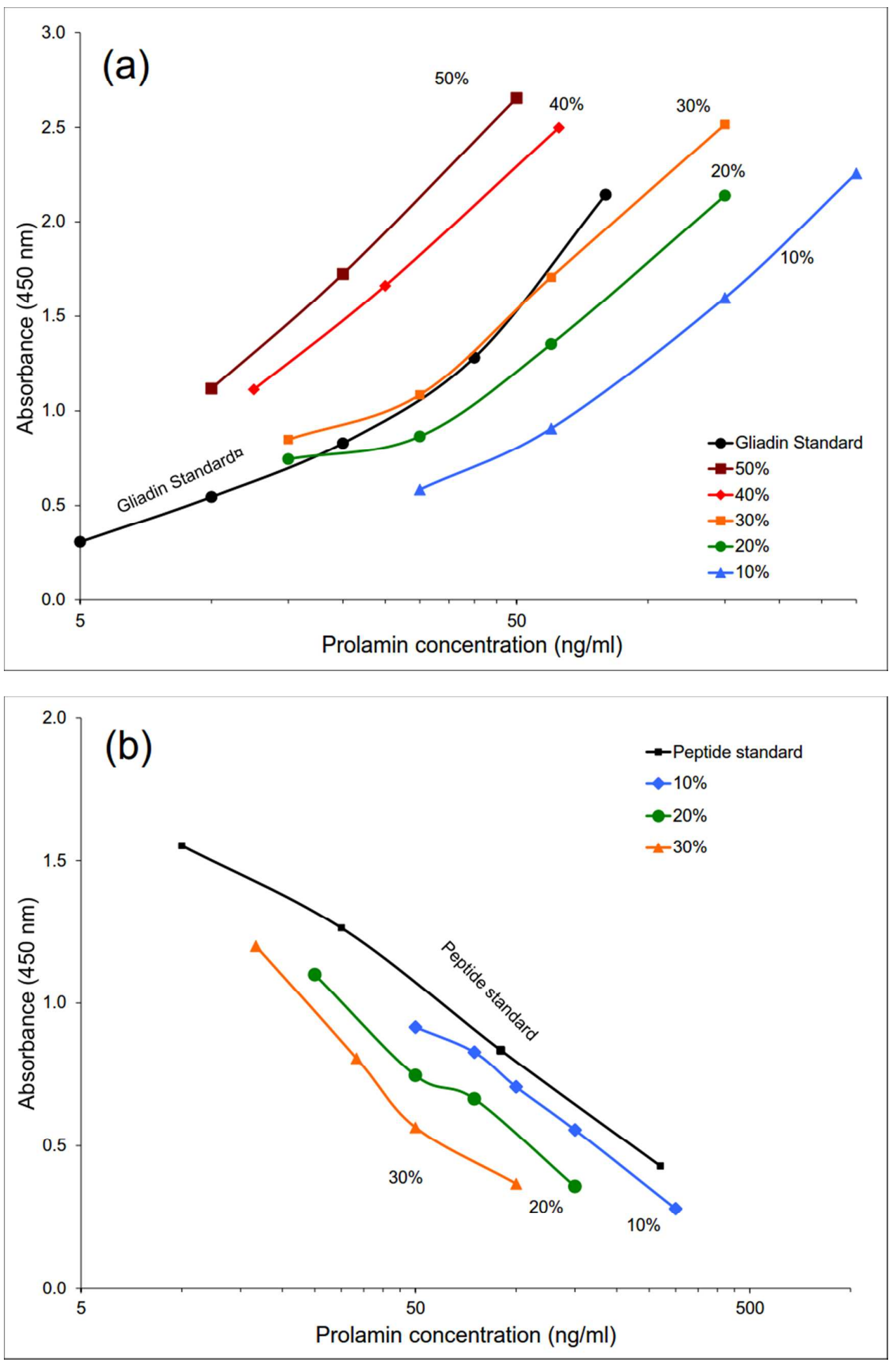


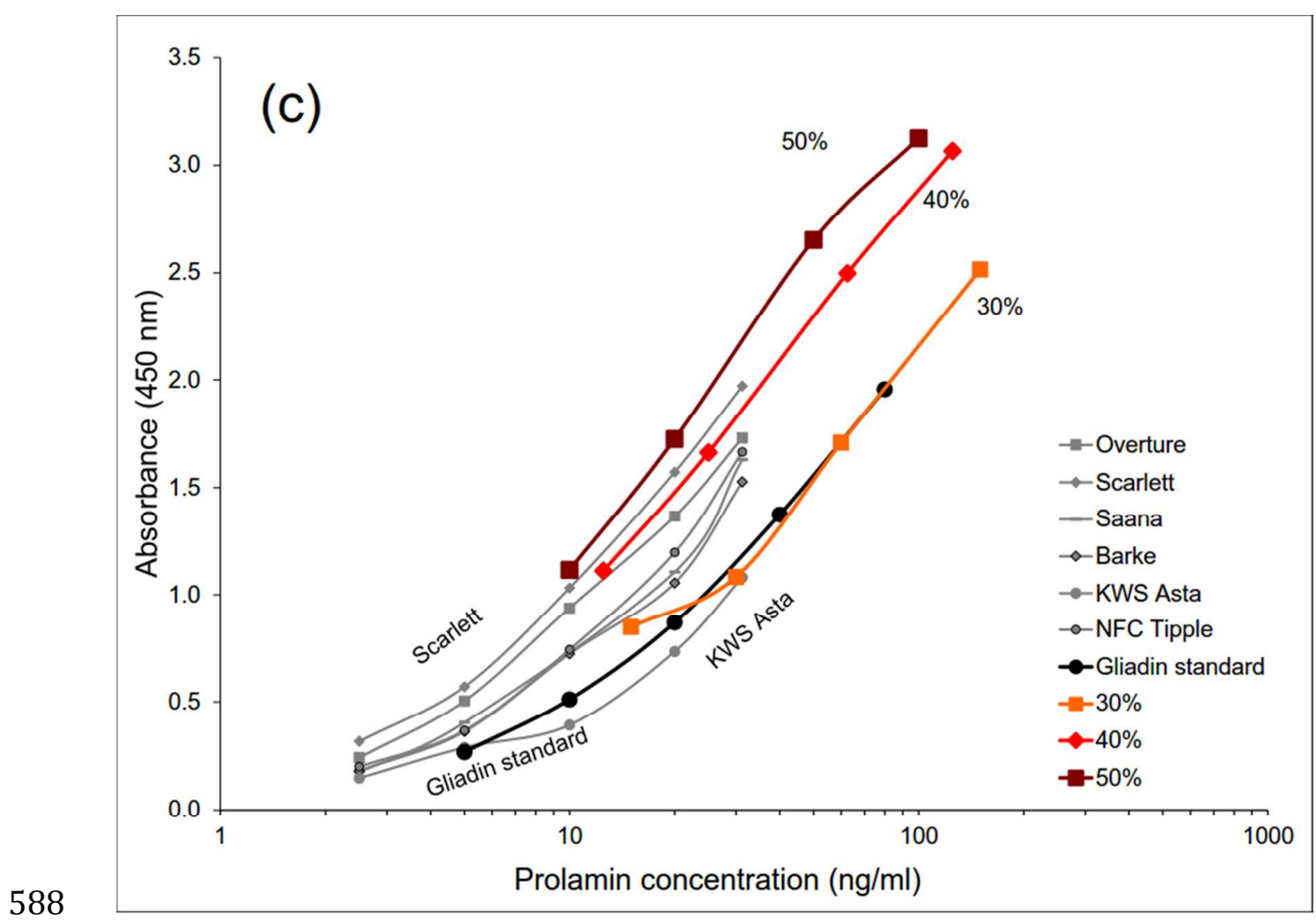


$590 \quad$ Figure 5

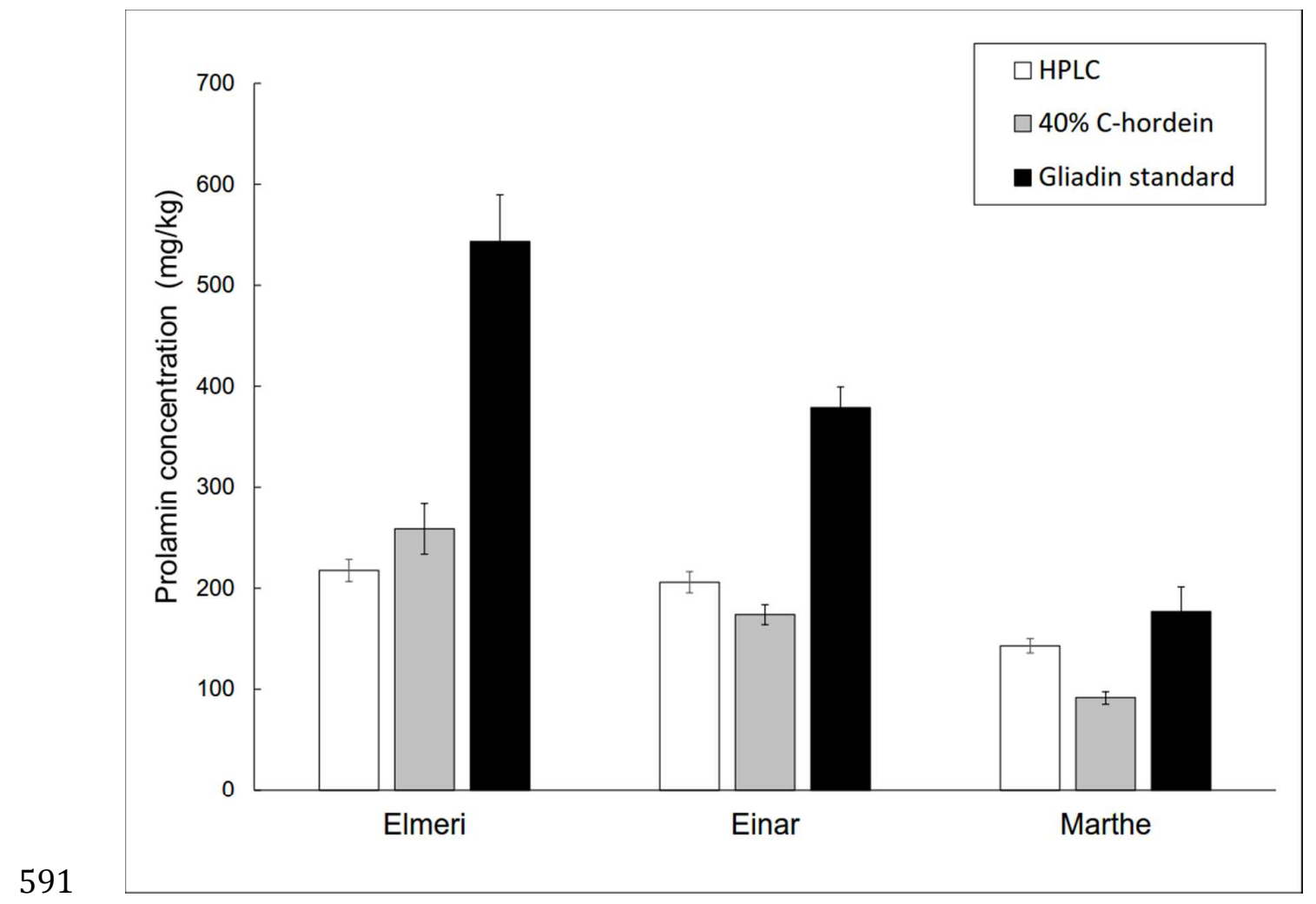

